\title{
THE EFFECTIVENESS OF INFORMATION AND COMMUNICATION TECHNOLOGY (ICT) IN LEARNING ISLAMIC EDUCATION
}

\author{
Waluyo Erry Wahyudi \\ Universitas Islam Negeri of Raden Intan Lampung, Indonesia \\ Email: waluyoerrywahyudi@gmail.com
}

DOI: 10.35445/alishlah.v12i1.134

Accepted: July $8^{\text {th }}, 2019$. Approved: June $24^{\text {th }}, 2020$.

Published: June $30^{\text {th }}, 2020$

\begin{abstract}
The purpose of this research was to know the effectiveness of information and communication technology (ICT) in learning Islamic education in junior high school tunas dharma Lampung Selatan. The technique of data analysis used qualitative analysis, namely the research discussesed about the problem how the effectiveness of information and communication technology (ICT) in learning islamic education in junior high school tunas dharma Lampung Selatan. Based on the results of the data from the research and after the data was analyzed, it can be concluded that the Application of Information and Communication Technology (ICT) runs effectively realized by several indicators included: In the learning process which used the Internet as outlined in the RPP, able to create and design on the web, able to answer issues related to Information and communication Technology (ICT) which contained in interviews and increase students learning result of Class IX A. The average score on the cognitive side, namely above the KKM was 29 students or $80.55 \%$ and below the KKM was 7 students or $19.44 \%$.
\end{abstract}

Keywords: Information and Communication Technology, Islamic Education Learning

\section{EFEKTIVITAS TEKNOLOGI INFORMASI DAN KOMUNIKASI (TIK) DALAM PEMBELAJARAN PENDIDIKAN AGAMA ISLAM}

\begin{abstract}
Abstrak
Tujuan penelitian ini adalah untuk mengetahui efektivitas teknologi informasi dan komunikasi (TIK) dalam pembelajaran PAI di SMP Tunas Dharma Kabupaten Lampung Selatan. Adapun teknik analisa data menggunakan analisis kualitatif, yakni penelitian yang membahas masalah bagaimana efektivitas teknologi informasi dan komunikasi dalam pembelajaran Pendidikan Agama Islam di SMP Tunas Dharma Kabupaten Lampung Selatan. Berdasarkan hasil data yang diperoleh dari penelitian, dan setelah data dianalisa maka dapat disimpulkan bahwa Penerapan Teknologi Informasi dan
\end{abstract}


Al-Ishlah: Jurnal Pendidikan - ISSN: 2087-949o (p); 2597-940X (e)

Vol. 12, No. 1 (2020)

Komunikasi (TIK) berjalan efektif terlihat dari beberapa indikator diantaranya: Dalam proses pembelajaran telah menggunakan media Internet yang tertuang dalam RPP, mampu membuat dan mendesain layanan di web, mampu menjawab persoalan-persoalan yang terkait dengan Teknologi Informasi dan komunikasi (TIK) yang tertuang dalam wawancara serta meningkatnya hasil belajar siswa kelas IX A memperoleh nilai ratarata dari segi kognitif yaitu di atas KKM 29 orang atau 80,55\% dan dibawah KKM 7 orang atau $19,44 \%$.

Kata Kunci : Teknologi Informasi dan Komunikasi, Pembelajaran PAI

\section{PENDAHULUAN}

Pada pembelajaran tradisional pendidik menyampaikan ilmu pengetahuan atau informasi kepada siswa, artinya guru lebih mendominasi dalam proses pembelajaran. Siswa hanya menerima dari pendidik dengan mencatat atau menghafalnya. siswa hanya berinteraksi dengan pendidik. Aktivitas siswa terlihat formal, kaku, tidak bervariasi. Materi siswa yang bersumber dari buku paket pelajaran. Media siswa umumnya papan tulis dan buku cetak. Pengelolaan kelas dilakukan di kelas dan para siswa duduk menetap selalu menghadap ke papan tulis (Munir, 2010).

Proses belajar yang berbasis Teknologi Informasi dan Komunikasi (TIK) di dunia pendidikan keberadaannya tidak bisa dipisahkan pada tuntutan pembelajaran abad 21 . Bagian perspektif pendidikan global, TIK merupakan soko guru (penopang) efektifnya penerapan pendidikan. Bahkan, TIK bagian perkembangannya memperkenalkan semua komponen-komponen pendidikan yang mutakhir, pengajar, peserta didik, wali murid dan lembaga diminta untuk menyesuaikan dalam mengambil sikap. Dalam konteks, pembelajaran berbasis TIK membawa tuntutan-tuntutan nanti harus dipenuhi oleh lembaga. Misalnya, guru dalam menyusun pembelajaran, melaksanakan dan menggunakan sistem penilaiannya mengalami perubahan. TIK yang semula hanya sebagai alat bantu, bagian perkembangannya mempunyai peran lebih jauh dari itu. Oleh karena itu cara belajar siswa pun mengalami perubahan. Berbagai model pembelajaran yang telah tersedia dapat dipadukan bersama TIK. Intinya reposisi pembelajaran di lembaga perlu dilakukan secara bijak. Pentingnya penelitian ini untuk mengetahui bagaimana cara belajar yang efektif dan efisien bagi pengajar dan peserta didik. Yang membedakan dengan penelitian sebelumnya adalah penulis meneliti tentang efektivitas teknologi informasi dan komunikasi (TIK) dalam pembelajaran PAI di SMP Tunas Dharma Kabupaten Lampung Selatan.

Berbagai program-program simulasi, animasi dan laboratorium virtual (maya) dapat digunakan untuk mendukung proses pembelajaran. Berbagai upaya untuk meningkatkan minat, motivasi, percaya diri dan berbagai keterampilan yang dipersyaratkan dalam pembelajaran yang tertuang dalam tujuan pembelajaran terus diupayakan. Intinya, kita tidak bisa bayangkan betapa lengkapnya mesin pencari seperti google, yahoo dan alat bantu pencari lainnya untuk membantu mencari informasi yang dibutuhkan dengan sangat mudah dan cepat bagi para pengguna. Di samping itu, kehadiran facebooks, e-mail, aneka software yang tersedia cukup memadai sebagai alat 
Al-Ishlah: Jurnal Pendidikan - ISSN: 2087-949o (p); 2597-940X (e)

Vol. 12, No. 1 (2020)

bantu dalam pembelajaran. Kedua komponen tersebut merupakan indikator-indikator penting memanfaatkan TIK dalam pembelajaran (Sutrisno, 2012).

Pendidikan Islam ialah pendidikan yang diciptakan, dilaksanakan dan ditujukan untuk umat Islam (Abuddin Nata, 2016). Pendidikan menurut Islam atau pendidikan yang Islami, yaitu pendidikan yang dapat dimengerti serta diluaskan dari pengajaran serta nilainilai sangat penting dimuat dengan asal dasarnya, yaitu Alquran dan Hadits Pada penjabaran ini, pendidikan Islam bisa berbentuk teori serta pemikiran pendidikan yang berdasarkan diri serta dapat didirikan juga diperkaya dari asal atau sumber-sumber dasar tersebut.

Berdasarkan hasil wawancara dan pengamatan pra-survey pada guru pendidikan agama Islam kelas IX A di SMP Tunas Dharma Kabupaten Lampung Selatan. Didapati dalam proses pembelajaran yang dilakukan oleh guru di SMP Tunas Dharma Kabupaten Lampung Selatan masih menggunakan metode yang konvensional dan sumber belajar masih menggunakan media cetak (buku). Mereka enggan menggunakan media berbasis TIK karena pendidik menganggap media berbasis TIK akan membutuhkan banyak waktu dalam persiapan kegiatan belajar mengajar. Pihak sekolah sudah memberikan fasilitas TIK seperti LCD proyektor, komputer dan wifi. Namun fasilitas yang diberikan sekolah seperti wifi untuk akses internet belum bisa digunakan secara optimal oleh peserta didik dalam kegiatan pembelajaran, hal tersebut disebabkan pendidik takut akan ada penyimpangan dalam penggunaannya dan pendidik telah menggunakan media TIK namun penggunaan media TIK hanya sekedar menampilkan apa yang akan dipresentasikan dengan menggunakan media komputer dengan aplikasi microsoft powerpoint beserta LCD proyektor.

Memasuki Teknologi Informasi dan Komunikasi (TIK) saat ini amat dirasakan keperluan dan utamanya pemakaian ICT (Information and Communications Technology) pada aktivitas pembelajaran. Berawal penggunaan TIK kita bisa meningkatkan kualitas pembelajaran, ialah menggunakan cara melihat secara luas pada jalan ilmu pengetahuan dan penerapan pembelajaran berkualitas, terpenting dengan mengimplementasikan high tech dan high touch approach. Dalam penelitian ini di dukung oleh para pengelola sekolah khususnya kepala sekolah, waka kurikulum, guru dan peserta didik. Penggunaan Teknologi informasi dan komunikasi menyediakan cakupan yang luas, cepat, efektif dan efisien dari penyebaran informasi ke berbagai belahan dunia. Teknologi informasi dikembangkan seiring dengan perkembangan teori dan komunikasi serta teknologi yang beradaptasi dengan praktik kegiatan pembelajaran. Pembelajaran Berdasar Komputer (PBK), Pembelajaran Berdasar Web (e-learning) Pembelajaran berdasar komputer (CAI), Pembelajaran berdasar Audio-Visual (AVA), pembelajaran berbasis multimedia ialah salah satu cara pendayagunaan Teknologi Informasi dan komunikasi yang penting dijalankan pada dunia pendidikan sekarang ini. aktivitas pembelajaran merupakan aktivitas yang lebih penting dalam kesemua proses pendidikan. Hal ini mempunyai arti sesungguhnya pemenuhan sasaran pendidikan banyak bersandar pada bagaimana prosedur pembelajaran didesain dan dijalankan secara cakap. Sering kali pelaksanaan pembelajaran selalu menghubungkan dua pelaku aktif, yaitu guru dan siswa.

Pendidik ialah pembuat suasana belajar peserta didik yang dirancang secara terencana, terstruktur, dan berkelanjutan. Sedangkan siswa sebagai peserta didik adalah 
Vol. 12, No. 1 (2020)

pihak yang merasakan keadaan belajar yang dibuat pengajar. Percampuran dari kedua unsur manusiawi ini memberikan hubungan pendidikan dengan memanfaatkan Teknologi Informasi dan Komunikasi sebagai mediumnya. Internet salah satu bagian dari Teknologi Informasi dan Komunikasi. Internet dapat mempermudah pencarian informasi terkait dengan pembelajaran, adanya variasi metode pembelajaran yang menarik khususnya dapat lebih cepat dan tepat dalam mencapai tujuan pembelajaran PAI di SMP Tunas Dharma Kabupaten Lampung Selatan.

Pembelajaran adalah sistem komunikasi dua arah. Dalam hal ini kegiatan membimbing dilakukan oleh pengajar. Sedangkan kegiatan belajar dilakukan oleh siswa (Sagala, 2013). Definisi lain dari Pembelajaran ialah suatu usaha yang dilaksanakan oleh pengajar untuk membelajarkan siswa yang belajar (Tim Pengembang MKDP, 2015). Pada pendidikan formal, pembelajaran merupakan jabatan yang dibebankan kepada pengajar karena pengajar adalah tenaga profesional yang disediakan untuk itu. Dalam menjalani pengajaran pendidikan agama Islam yang tepat dan cermat, pengajar mesti sungguh-sungguh mengusahakan jalan yang terbaik sehingga dapat diperoleh dengan mudah oleh siswa, hal ini juga bisa diteladani dari firman Allah SWT. dalam surat AnNahl:125 sebagai berikut:

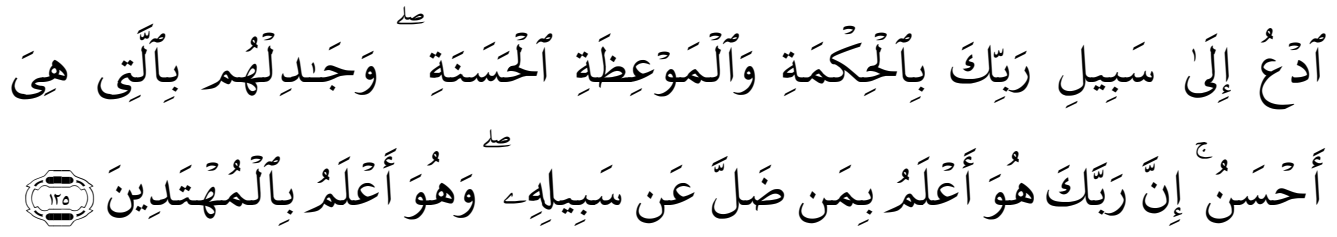

Artinya: "serulah (manusia) kepada jalan Tuhanmu dengan hikmah dan pelajaran yang baik dan bantahlah mereka dengan cara yang baik. Sesungguhnya Tuhanmu Dialah yang lebih mengetahui tentang siapa yang tersesat dari jalan-Nya dan Dialah yang lebih mengetahui orang-orang yang mendapat petunjuk." (Q.S An-Nahl:125) (Departemen Agama RI, 2009)

Dari ayat di atas dipahami bahwa dengan menganjurkan orang untuk mempercayai nilai-nilai ajaran Islam, seseorang mesti hidup dengan cara bijaksana, pelajaran yang baik dan alasan yang dapat diperoleh dari orang lain. Oleh karena itu, melalui penyampaian pembelajaran kepada siswa, seseorang harus hidup dengan cara terbaik sehingga dapat berfungsi secara efektif dan efisien.

Aktivitas dalam pembelajaran tidak hanya sekedar aktivitas mengajar yang melalaikan aktivitas belajar, ialah hanya merancang pengajaran dan menjalankan tahap mengajar dalam pembelajaran tatap muka. Akan tetapi, aktivitas pembelajaran lebih pelik lagi dan dijalankan menggunakan model-model pembelajaran yang beragam.

Berdasarkan pengertian pendidikan agama Islam dapat ditentukan sebagian hal yang penting dilihat dalam pembelajaran PAI, ialah:

a. Pendidikan agama Islam sebagai usaha sadar yakni suatu aktivitas tuntunan, teladan dan latihan yang dilaksanakan dengan cara berencana juga sadar dalam mencapai tujuan pendidikan.

b. Siswa yang akan disiapkan untuk menggapai tujuan pendidikan. 
Al-Ishlah: Jurnal Pendidikan - ISSN: 2087-949o (p); 2597-940X (e)

Vol. 12, No. 1 (2020)

c. Aktivitas pembelajaran PAI ditujukan agar meningkatkan akidah, penafsiran, penjiwaan dan penerapan ajaran agama Islam dari siswa, selain untuk mewujudkan manusia yang berakhlak baik.

Penelitian ini penting untuk dilakukan agar para guru studi PAI khususnya dan para guru bidang studi lain secara umum dapat menjadikan hasil penelitian ini sebagai bahan referensi dalam proses pembelajaran. Hasil dari penelitian ini diharapkan dapat menambah pengetahuan, keterampilan dan penggunaan fasilitas dan infrastruktur TIK oleh guru.

\section{METODE PENELITIAN}

Penelitian ini merupakan penelitian kualitatif. Penelitian ini menyampaikan gejala suatu tradisi tertentu yang secara fundamental tergantung pada pengamatan manusia dalam kawasannya sendiri dan berkaitan dengan orang-orang tersebut dalam bahasanya dan peristilahannya (Moleong, 2017). Metode yang dipakai pada pengumpulan data adalah dengan memakai observasi, interview (wawancara), dan dokumentasi. Penelitian ini dilakukan untuk menggambarkan atau menjelaskan secara sistematis, faktual dan akurat mengenai fakta dan sifat populasi tertentu. (Wina Sanjaya, 2013). Sumber data dalam penelitian ini adalah sebagai berikut:

1. Waka Kurikulum SMP Tunas Dharma Kabupaten Lampung Selatan

2. Guru Pendidikan Agama Islam SMP Tunas Dharma Kabupaten Lampung Selatan

3. Para siswa yang terlibat dalam kegiatan program Pembelajaran PAI di SMP Tunas Dharma Kabupaten Lampung Selatan

Fakta-fakta dan sifat populasi dikumpulkan secara keseluruhan, kemudian ditarik kesimpulan. Jadi, dalam penelitian ini penulis berusaha meneliti tentang Efektivitas Teknologi Informasi dan Komunikasi dalam Pembelajaran Pendidikan Agama Islam di SMP Tunas Dharma Kabupaten Lampung Selatan. Kemudian data diproses melalui runtunan analisa, dicek secara terus menerus dan berulang-ulang, supaya mewujudkan kesimpulan akhir yang menyeluruh dan mendalam.

\section{HASIL DAN PEMBAHASAN}

1. Hasil Belajar Siswa Kelas IX A Mata Pelajaran PAI Sebelum Menggunakan Teknologi Informasi dan Komunikasi (TIK) Tahun Pelajaran 2018/2019



Sumber: Dokumentasi SMP Tunas Dharma Kabupaten Lampung Selatan 
Al-Ishlah: Jurnal Pendidikan - ISSN: 2087-949o (p); 2597-940X (e)

Vol. 12, No. 1 (2020)

Hasil belajar Pendidikan Agama Islam sebelum penerapan teknologi informasi dan komunikasi SMP Tunas Dharma menunjukkan bahwa dalam proses pembelajaran masih banyak yang memperoleh nilai di bawah KKM. Diagram bentuk batang di atas menunjukkan dengan jelas banyak siswa yang memperoleh nilai di bawah KKM dikarenakan belum maksimalnya penerapan TIK di SMP Tunas Dharma Kabupaten Lampung Selatan. nilai di bawah KKM yaitu 17 siswa atau $47,22 \%$ dan yang memperoleh nilai di atas KKM 19 siswa atau 52,77\%.

2. Hasil Belajar Siswa Kelas IX A Mata Pelajaran PAI Sesudah Menggunakan Teknologi Informasi dan Komunikasi (TIK) Tahun Pelajaran 2018/2019

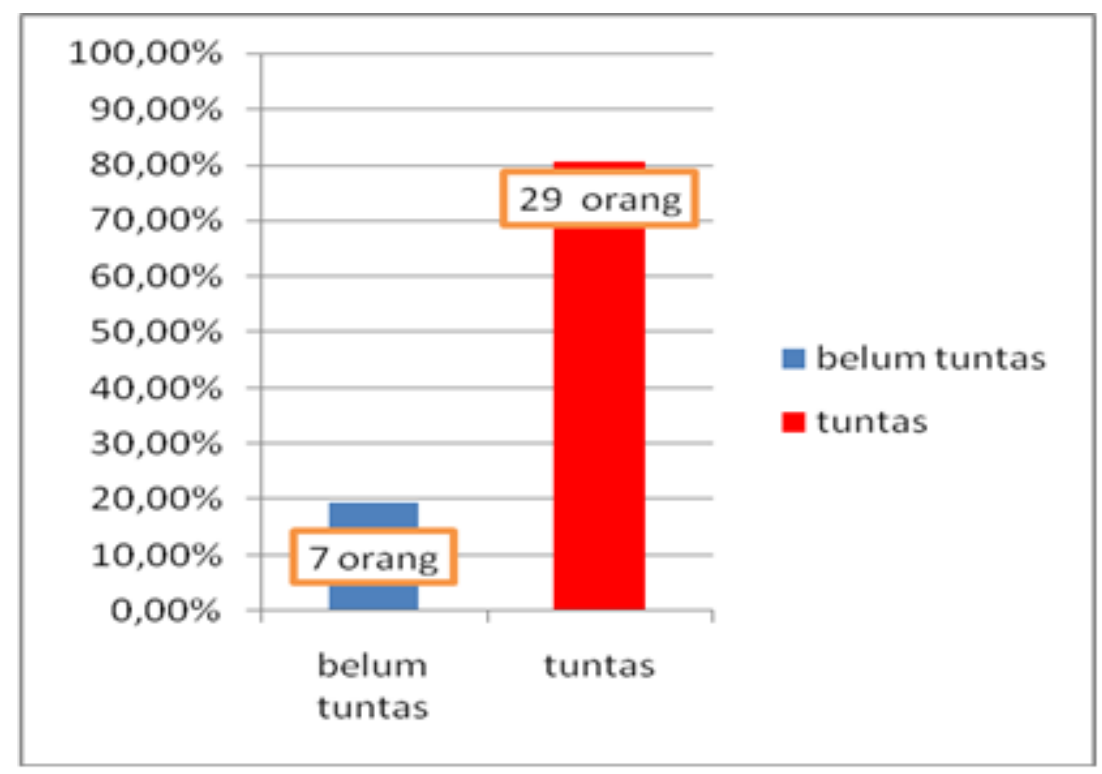

Sumber: Dokumentasi SMP Tunas Dharma Kabupaten Lampung Selatan

Peningkatan kualitas belajar mengajar juga dapat dilihat dari penggunaan internet di SMP Tunas Dharma, Kabupaten Lampung Selatan. Dalam hal ini telah dilakukan upaya dalam peningkatan kemampuan menggunakan website. Kegiatan dalam menggunakan website yang disediakan pihak sekolah juga merupakan pembiasaan menggunakan internet untuk mendukung peningkatan kualitas kegiatan belajar mengajar di kelas. Peran Internet di sini adalah menyediakan konten yang sangat kaya akan sumber belajar dan juga menyediakan tautan ke berbagai sumber belajar. Jadi, website dan penggunaan internet di sini merupakan media pembelajaran untuk menemukan materi pembelajaran. Diagram batang di atas menunjukkan dengan jelas banyak siswa yang memperoleh nilai di atas KKM dikarenakan sudah adanya penerapan TIK di SMP Tunas Dharma Kabupaten Lampung Selatan. Siswa yang memperoleh nilai di atas KKM adalah 29 orang atau $80,55 \%$ dan di bawah KKM adalah 7 orang atau 19,44\%. Dapat disimpulkan bahwa penggunaan media pembelajaran berbasis internet, mampu meningkatkan hasil belajar siswa dalam pembelajaran agama islam.

Dari hasil wawancara diketahui bahwa pemanfaatan internet dalam belajar sebenarnya sudah dilaksanakan oleh guru sejak tahun 2008. Hanya saja penggunaannya belum maksimal. Sebagaimana penggunaan ICT dalam pembelajaran dengan menggunakan media pembelajaran berbasis internet akan mendorong siswa dalam 
Al-Ishlah: Jurnal Pendidikan - ISSN: 2087-949o (p); 2597-940X (e)

Vol. 12, No. 1 (2020)

mengikuti proses aktivitas belajar mengajar khususnya pembelajaran PAI. Cara menggunakan Internet di SMP Tunas Dharma, Kabupaten Lampung Selatan adalah bentuk peningkatan kursus web, yang merupakan penggunaan internet untuk mendukung peningkatan kualitas kegiatan belajar mengajar di kelas. Peran Internet di sini adalah menyediakan konten yang sangat kaya (sumber belajar) dan juga menyediakan tautan ke berbagai sumber belajar. Jadi, internet di sini digunakan sebagai sarana belajar mencari bahan belajar. Dengan menggunakan fasilitas yang tersedia di Internet, siswa dapat memperoleh sumber belajar yang diperbarui, yang akan menumbuhkan motivasi yang lebih besar untuk membaca dan mengikuti kemajuan dalam sains dan teknologi yang terjadi di berbagai belahan dunia. Hasil yang diperoleh dari pembahasan bahwa penerapan teknologi informasi dan komunikasi dalam Pembelajaran PAI di SMP Tunas Dharma Kabupaten Lampung Selatan diantaranya dalam menggunakan internet, berjalan efektif dengan hasil belajar yang meningkat.

Seiring perkembangan Teknologi Informasi dan Komunikasi dan infrastruktur pendukungnya, usaha peningkatan kualitas pendidikan berhasil dilakukan dengan memasukan ICT pada kegiatan pembelajaran. Kegiatan pembelajaran dilakukan dengan pembelajaran Berbasis Teknologi Informasi dan Komunikasi. Melalui sarana yang diberikan oleh sistem tersebut, pendidik dan peserta didik dapat mengeksplorasi dan mengelaborasi aktivitas belajar dan mengajar secara efektif dan efisien (Rusman, dkk, 2011).

\section{SIMPULAN}

Penerapan Teknologi Informasi dan Komunikasi dalam Pembelajaran PAI di SMP Tunas Dharma Kabupaten Lampung Selatan dengan menggunakan internet berjalan efektif. Hal ini terlihat dari Dalam proses pembelajaran telah menggunakan media internet yang tertuang dalam RPP, mampu membuat dan mendesain layanan di web, mampu menjawab persoalan-persoalan yang terkait dengan Teknologi Informasi dan komunikasi (TIK) yang tertuang dalam wawancara serta meningkatnya hasil belajar siswa kelas IX A memperoleh nilai rata-rata dari segi kognitif (KKM) adalah 29 orang atau 80,55\% dan di bawah KKM 7 orang atau 19,44\%.

\section{DAFTAR PUSTAKA}

Abuddin Nata. (2016). Ilmu Pendidikan Islam. Jakarta: Prenadamedia Group.

Departemen Agama RI. (2009). Al-Qur'an dan terjemahnya. Bandung : PT Sygma Examedia Arkanlema.

Lexy J. Moleong. (2017). Metode Penelitian Kualitatif. Bandung: Remaja Rosdakarya.

Munir. (2010). Kurikulum Berbasis Teknologi Informasi dan Komunikasi. Bandung: Alfabeta. 
Al-Ishlah: Jurnal Pendidikan - ISSN: 2087-949o (p); 2597-940X (e)

Vol. 12, No. 1 (2020)

Rusman, dkk. (2011). Pembelajaran Berbasis Teknologi Informasi dan Komunikasi. Bandung: PT RajaGrafindo Persada.

Rusman. (2014). Model-Model Pembelajaran: Mengembangkan Profesionalisme Guru. Jakarta: Rajawali Pers.

Sugiyanto. (2010). Model-Model Pembelajaran Inovativ. Surakarta: Yuma Pustaka bekerjasama dengan FKIP UNS.

Sutrisno. (2012). Kreatif Mengembangkan Aktivitas Pembelajaran Berbasis TIK. Jakarta: Referensi.

Syaiful Sagala. (2013). Konsep dan Makna Pembelajaran. Bandung: Alfabeta.

Tim Pengembang MKDP. (2015). Kurikulum dan Pembelajaran. Jakarta: Rajawali Pers.

Wina Sanjaya. (2013). Penelitian Pendidikan. Jakarta: Kencana. 